\title{
Determinants of Customer Loyalty: The Role of Service Quality, Customer Satisfaction and Bank Image of Islamic Banks in Palestine \\ Feras MI Alnaser ${ }^{1 *}$, Mazuri Abd Ghani1 , Samar Rahi' ${ }^{1}$, Majeed Mansour $^{2}$ and Hussein Abed ${ }^{3}$
}

${ }^{1}$ Faculty of Economics and Management Sciences, Universiti Sultan Zainal Abidin, Terengganu, Malaysia

${ }^{2}$ Faculty of Administrative and Financial Sciences, Arab American University, Jenin, Palestine

${ }^{3}$ Human Resource Manager, An-Najah National University, Nablus, Palestine

\begin{abstract}
The aim of this study is to determine the role of service quality, customer satisfaction and bank image on customer loyalty and recommendation of the Islamic banks in Palestine. The confirmatory factor analysis was used to determine the different variables that were being studied in this research paper and their relationship with customer loyalty and recommendation. The research findings showed that customer satisfaction normally has an impact on the bank image a customer will create, ultimately affecting his or her customer loyalty and recommendation to a certain bank. Customer satisfaction is determined by the quality of services that he or she experiences in a bank. Therefore, if a customer receives service quality that meets or exceeds his or her expectations, then he or she will have a positive image of the bank, become satisfied and then will highly likely be loyal to a particular financial institution and recommend it to his or her friends
\end{abstract}

Keywords: Customer loyalty; Service quality; Customer satisfaction; Bank image

\section{Introduction}

Islamic banking in Palestine is considered to be still at its infancy stage. However, it has been able to capture a lot of interest and support in the region mainly because of its attractive products and the role of Islamic banking in Palestine economy [1]. Some of the products and services that these banks offer to their customers include interest free loans, and entering into parallel contracts with their customers in business transactions whereby; the two parties share profits and losses, and it has led to creation of wealth [2]. From an economic perspective, Islamic banks have contributed to a flow of wealth between people, provision of capital to start different business projects, and it has contributed to establishing of new jobs in Palestine.

Service quality is considered to be an intangible, variable and it is regarded as an integral characteristic, which is seen as unique to the services that are offered. Due to the increase of global competition, providing quality service is considered to be a key for success. Most marketing experts believe that service quality is among the top strategies that are currently shaping the marketing and business strategy [3]. For banks to increase the number of customers that they serve on a regular basis they should not only provide good quality products; they should also be willing to render excellent services to satisfy their customers' needs.

In reference to customer satisfaction, it is a measure of how different products or services that have been supplied by a company will meet or surpass a customer's expectation. It is mainly used by businesses and market owners as a metric in order to manage and improve a business in terms of the products and services that are being offered to the customers [4]. It is also considered to be a leading indicator in terms of assessing a consumer's repurchase intentions and also loyalty. It is important to point out that the brand image of the Islamic banks is determined by the impression that the targeted customers have in relation to that brand [5]. As has been pointed out, Islamic banks have managed to build a positive image in Palestine based on the products that they offer, and that they ensure that the bank customers can manage to conduct their bank transactions while observing the religious teachings in relation to financial dealings [6].
The objective of this study is to assess the role of service quality, customer satisfaction, and bank image of the Islamic banks in Palestine on customer loyalty and recommendation. The paper begins with a review of the literature on the different aspects that have been mentioned. Hypotheses were then developed to conduct tests and also illustrate the empirical approach and then perform data collection [7]. The implications of the findings were then discussed, conclusions made with various recommendations.

\section{Literature Review}

The impact of service quality on customer satisfaction and customer loyalty in the context of banking sector is a widely discussed topic in the literature. This section targets service quality dimensions as well as customer satisfaction and customer loyalty.

\section{Service quality}

A service is defined as an action that is meant to be beneficial to a customer. Therefore, service quality is considered to be the difference between the expected performance of a certain service, and its actual performance [8]. Service quality is seen as the extent in which a certain service fulfills the expectations of the customers. It normally determines the impression that a customer will have towards a certain product or service. A brief explanation of these dimensions is given below.

Tangibles: Those things which have a physical existence and can be seen and touched. In context of service quality, tangibles can be

*Corresponding author: Feras MI Alnaser, Faculty of Economics and Management Sciences, Universiti Sultan Zainal Abidin, Terengganu, Malaysia, Tel: +60 9-668 8888; E-mail: sunvictory5@gmail.com

Received September 14, 2017; Accepted September 20, 2017; Published September 21, 2017

Citation: Alnaser FMI, Ghani MA, Rahi S, Mansour M, Abed H (2017) Determinants of Customer Loyalty: The Role of Service Quality, Customer Satisfaction and Bank Image of Islamic Banks in Palestine. Int J Econ Manag Sci 6: 461. doi: 10.4172/2162-6359.1000461

Copyright: (c) 2017 Alnaser FMI, et al. This is an open-access article distributed under the terms of the Creative Commons Attribution License, which permits unrestricted use, distribution, and reproduction in any medium, provided the original author and source are credited. 
referred to as Information and Communications Technology (ICT) equipment, physical facilities and their appearance (ambience, lighting, air-conditioning, seating arrangement); and lastly but not least, the services providing personnel of the organization. These tangibles are deployed, in random integration, by any organization to render services to its customers who in turn assess the quality and usability of these tangibles.

Reliability: Reliability means the ability of a service provider to provide the committed services truthfully and consistently. Customers want trustable services on which they can rely.

Assurance: Assurance is developed by the level of knowledge and courtesy displayed by the employees in rendering the services and their ability to instill trust and confidence in customer.

Empathy: Empathy means taking care of the customers by giving attention at individual level to them. It involves giving ears to their problems and effectively addressing their concerns and demands.

\section{Customer satisfaction}

As has been stated before, customer satisfaction refers to an organization fulfilling its customer's expectation in relation to the products and services that it offers. Therefore, if the perceived performance matches or it exceeds his or her expectation, then the customer will be satisfied, however, if it is not, then it is highly likely that they will be dissatisfied. In relation to this theory, it has been determined that prior to the purchase of a product or service, consumers have certain expectations on how a product will fulfill a certain need. The expectations that the consumers have are derived from past experiences of the product or similar products, and the existing attitudes held by a customer. There are different approaches that can be used to determine customer satisfaction in relation to a certain product.

The first one is the transaction-specific evaluation which focuses on a customer's feelings in response to a certain product or service that they wish or have purchased. A customer may become satisfied or dissatisfied with a product based on its cost and what he or she assumed it will fulfill. The other approach focuses on customer satisfaction or dissatisfaction as cumulative satisfaction. In this paper, it establishes how customer satisfaction level affects their loyalty in relation to Islamic banks in Palestine.

Previous studies on customer satisfaction of the Islamic banking industry have established that there are different factors that determine customer satisfaction and therefore their loyalty levels. Othman and Owen [9] established that a majority of Kuwait Islamic banking customers are satisfied due to their overall and personal contact with the banking staff. In another study that assessed customer satisfaction levels in Malaysian banks, various factors such as fast and efficient services, confidentiality, and transaction speeds are the things that determine customer satisfaction levels. It is important for Islamic banks in Palestine to establish the various factors that affect their consumers, if they want to increase their consumer base.

\section{Customer loyalty}

Generally, every banking company aims at earning profits, expanding its business by offering more diversified products or services over time and capturing a larger market share progressively. Customer loyalty can favorably contribute towards this basic aim of the banks as it is an effective tool for generating repeat sales from the customers. Furthermore these loyal customers can serve as effective elements in the marketing mechanism when they refer their bank to more people. In this way these existing customers contribute towards increasing their respective bank's Khan and Fasih 335 customer base and market share. The financial base of any bank is largely dependent on this phenomenon.

\section{Bank image}

The Islamic bank images from the customers perspective is the association that they have when they hear the name or while they are conducting their transactions with these institutions. Image has both a functional and emotional component. Functional component focuses on tangible dimensions that are easy to identify and measure. On the other hand, emotional component is the psychological aspects that are determined by an individual's experience and attitude towards a certain organization. The image that customers will have in relation to the Islamic banks is a result of their experiences, beliefs, feelings and knowledge that they have about these institutions.

\section{Conceptual Framework and Hypotheses}

\section{Underpinning theory}

In this theory, customer loyalty is determined using the cognitiveaffect-conation pattern model. This model assesses customer loyalty at different stages when they are interacting with a certain product. There are three stages of assessment-cognitive loyalty-affective, loyaltyconative, and loyalty-action stages. In the first phase, a customer's loyalty is based on the experience that he or she has been provided in relation to the product. At this point, a customer's loyalty is inconsequential mainly due to the fact that the opinion that he or she has in regards to a certain product is based on other people's opinions rather than his or her own opinion. The second phase is known as affective loyalty, and during this period, a fondness of the product or service that an organization provides will have started being developed based on experience. The next phase is conative loyalty, which will be established through the satisfaction of repeated events in relation to the products or services provided by an organization to its customers.

\section{Relationship between different variables}

Various studies have provided empirical evidence that illustrate customer satisfaction is positively linked to the image, which ultimately determines customer loyalty and recommendation. Bontis et al. state that a company's reputation can be significantly improved if the organization focuses on satisfying its customers. Andreassen and Lindestad [10] pointed out that higher customer satisfaction will ultimately contribute to a higher reputation, which will have a positive influence on a company's overall image. Amin et al. also demonstrated that customer satisfaction has a positive influence or impact on the overall customer loyalty.

The impact of perceived service quality and how it affects customer loyalty is seen to be one of the most researched topics in marketing theory. Shannak et al. [11] pointed out that by improving service quality, an organization will be able to achieve a competitive advantage, and this will ultimately lead to customer loyalty. Gilbert and Veloutsou stated that most companies are now focusing on improving their service quality in order to attract more customers. Service quality is also regarded to be an antecedent of customer satisfaction, which determines customer loyalty. The following hypotheses were proposed in this study:

- Service quality has a positive influence on customer loyalty. 
- Customer satisfaction has a positive influence on bank image.

- Customer satisfaction has a positive influence on customer loyalty.

- Bank Image has a positive influence on customer loyalty.

\section{Methodology}

The purpose of this study is to have a better understanding of how different variables such as service quality, customer satisfaction, and bank images of Islamic banks in Palestine affect customer loyalty and recommendation. In this study, it applied the quota sampling technique, and in order to develop these quotas, the researcher listed relevant control characteristics, and then determined the distribution of these characteristics in the target population. The data was collected using structured questionnaires. The period of data collection was from July to early September ( $4^{\text {th }}$ of September 2017).

All the respondents of this study were Islamic bank customers (the respondents needed to have a bank account with an Islamic bank in order to be considered for this study). The researcher targeted bank customers from the following regions in West Bank, PalestineQalqilyah, Nablus, and Ramallah cities. The selection of bank branches in different regions was intended to ensure that there was generalizability of the findings of this study, and a representation of Islamic bank customers in the country.

Questionnaires were distributed to every fifth customer that visited a branch where the researcher was at a certain period. It is also important to point out that the researcher visited these banks at different times of day, various days of the week or month for sampling purposes. All the respondents who answered the questionnaires were assured of confidentiality. A seven-point Likert scale was used in order to determine customer perceptions in relation to service quality, customer satisfaction, and bank image, and their impact on customer loyalty. A score of (1) was strongly disagree, while that of (7) was strongly agree, with (3) representing a neutral score.

Service quality was measured using the SERVQUAL instrument as was proposed by Parasuraman [12]. Customer satisfaction indicators were measured by using the adapting scales that was developed by Fornell et al. Bank image was measured using the indicators that were proposed by Flavian et al.

\section{Data Analysis and Results}

\section{Demographics}

A total of 500 questionnaires were distributed, and 360 were returned - a $72 \%$ response rate. 125 of the respondents were male, and the remaining 235 were female.

\section{Measurement and model evaluation}

The confirmatory factor analysis was used in order to determine the pattern through which each measure loads on a certain factor. This run of the squared multiple correlations illustrated that a majority of the measurement items were $>0.5$ and therefore demonstrated a good reliability level. This meant that the measurement model retained the 15 observed indicators in order to estimate the model fit. Table 1 below illustrates the factor loadings, Cronbach's $\alpha$, average variance extracted (AVE) for the following variables - customer satisfaction, service quality, bank image and customer loyalty. In order to be able to determine the reliability of customer satisfaction, service quality,

\begin{tabular}{|c|c|c|}
\hline & AVE & A \\
\hline Customer Satisfaction & 0.72 & 0.881 \\
\hline Image & 0.73 & 0.885 \\
\hline Service Quality & 0.77 & 0.906 \\
\hline Customer Loyalty & 0.66 & 0.742 \\
\hline Islamic Banks & 0.78 & 0.931 \\
\hline
\end{tabular}

Table 1: Factor loadings.

\begin{tabular}{|c|c|c|}
\hline Hypotheses & Path & $\begin{array}{c}\text { Parameter } \\
\text { Estimate }\end{array}$ \\
\hline H1a & Customer satisfaction has a positive impact on bank image & 0.860 \\
\hline H1b & $\begin{array}{c}\text { Customer satisfaction has a positive impact on Customer } \\
\text { loyalty }\end{array}$ & 0.689 \\
\hline H2 & Service Quality has a positive impact on customer loyalty & 0.768 \\
\hline H3 & Bank Image has a positive impact on customer loyalty & 0.643 \\
\hline & Table 2: Hypotheses. \\
\hline
\end{tabular}

image, and customer loyalty instruments, the Cronbach's a coefficients were computed and all the results exceeded the minimum standard of 0.70 , an indication of a good estimate of internal consistency reliability. The results are as follows:

In order to test the hypothesis, a structural equation modeling approach was used. Using this modeling approach, the testing for invariance of the parameters was conducted through the application of constraints on different parameters. Table 2 shows the results of the hypotheses:

The results that have been illustrated in Figure 1 show that there is a positive relationship between customer satisfaction and bank image, which has a positive influence on customer loyalty. It therefore is in agreement with Hypothesis $1 \mathrm{a}, \mathrm{b}$, and 3 . Also based on the parameters estimate, it shows that service quality that is offered by a bank has a positive influence on customer loyalty, and therefore, it is in agreement with hypothesis 3 .

\section{Recommendation}

Various studies have recommended that customer satisfaction has a direct impact on bank image, which ultimately affects customer loyalty and recommendation [13]. A customer will form a certain perception of the bank that serves him or her based on the quality of the services that are provided to him or her [14]. The perception will be based on either experience or how a customer thinks he or she should be treated when being served by a bank. Customer satisfaction is normally experienced when the quality of the services that are offered meet or exceed the expectations of the customers [15]. It means that he or she will have a positive perception of the bank, and it will influence him or her to develop a sense of customer loyalty towards that bank. Over time he or she may recommend the bank to his or her friends.

\section{Conclusion}

As has been stated before, the purpose of this study is to establish the impact of service quality, customer satisfaction, and bank image on customer loyalty focusing on Islamic bank customers in Palestine [16]. Based on the initial findings of academic studies, a model was developed, and it showed that service quality, customer satisfaction, and bank image have a positive and direct effect on customer loyalty [17-20]. The researcher was able to establish that the three variables that were being studied have an impact on customer loyalty and will affect the rate at which a customer recommends a certain bank to his friends and family. For instance, if a customer is repeatedly provided with poor services when he or she visits a certain bank branch, he or she 


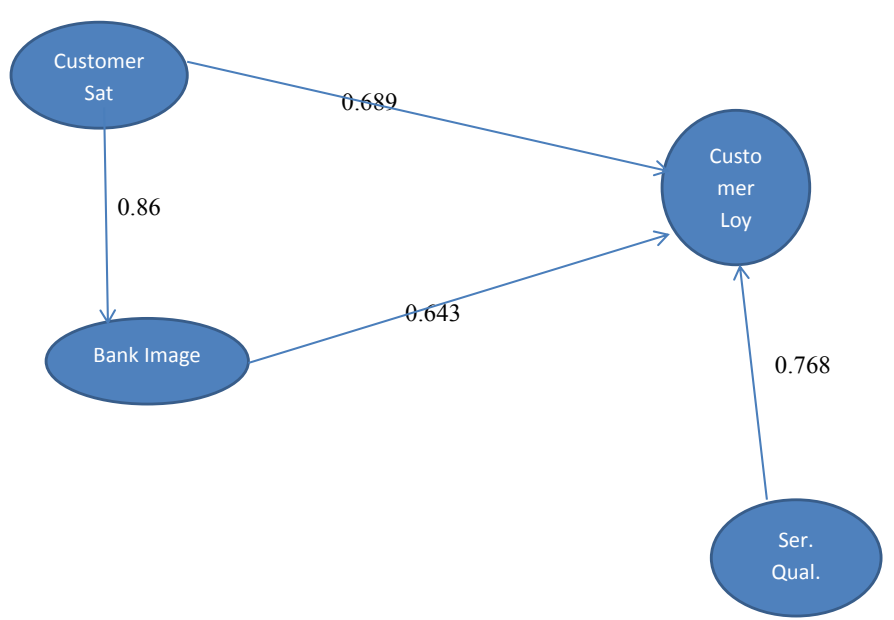

Figure 1: Positive relationship between customer satisfaction and bank image.

will begin associating the bank with poor qualities. Over time when he or she hears about that bank, he or she will form a negative image with that bank, and therefore it will have a negative impact on customer loyalty, and even recommendations. Therefore, it is important for the Islamic banks in Palestine to ensure that they provide essential services to the customers to the point that they meet or exceed their expectations.

\section{Limitation}

There are various limitations that were identified in this study. The first one is that, in this study it focused on a specific type of banking - Islamic banking. Therefore, caution needs to be taken when one attempts to make generalizations in both the banking and professional service industry. There is the need to conduct further research in relation to other professional service sectors such as commercial banking, tourism, and insurance. The other limitation was that the homogeneity of the study participants. Most of the bank customers in the West Bank religion are believed to be from a similar background and culture and this may have had an impact on the results of this study. There is the need to conduct a study in a heterogeneous region where the participants have potential differences, factors and this may affect the customer reactions towards various products. In future, it would be best if such a study is conducted in different countries in order for the findings to be generalized.

\section{References}

1. Reuters (2016) New Islamic Bank to open in the Palestinian territories. Reuters.

2. Kassim N, Asiah AN (2010) The effect of perceived service quality dimensions on customer satisfaction, trust, and loyalty in e-commerce settings. Asia Pacific Journal of Marketing and Logistics 22: 351-371.

3. Amin M, Isa Z, Fontaine R (2011) The role of customer satisfaction in enhancing customer loyalty in Malaysian Islamic banks. The Service Industries Journal 31: 1519-1532.

4. Flavián C, Torres E, Guinalíu M (2004) Corporate image measurement International Journal of Bank Marketing 22: 366-384.

5. Bravo R, Montaner T, Pina JM (2009) The role of bank image for customers versus non-customers. International Journal of Bank Marketing 27: 315-334.

6. Bontis N, Booker LD, Serenko A (2007) The mediating effect of organizational reputation on customer loyalty and service recommendation in the banking industry. Management Decision 45: 1426-1445.

7. Alshurideh DM, Al-Hawary SI, Mohammad AM, Al-Hawary AA, Al Kurdi BH
(2017) The Impact of Islamic Banks' Service Quality Perception on Jordanian Customers Loyalty. Journal of Management Research 9: 139.

8. Fornell C, Johnson MD, Anderson EW, Cha J, Bryant BE (1996) The American Customer Satisfaction Index: Nature, Purpose, and Findings. Journal of Marketing 60: 7-18.

9. Radman A, Othman M, Owen HL (2005) Managing and Measuring Custome Service Quality in Islamic Banks: A Study of the Kuwait Finance House. Islamic Perspectives on Wealth Creation, pp: 69-83.

10. Wallin AT, Lindestad B (1998) Customer loyalty and complex services International Journal of Service Industry Management 9: 7-23.

11. Shannak R, Masa'deh R, Al-Zu'bi Z, Obeidat B, Alshurideh M, et al. (2012) A theoretical perspective on the relationship between knowledge management systems, customer knowledge management, and firm competitive advantage. European Journal of Social Sciences 32: 520-32.

12. Parasuraman A, Zeithaml VA, Berry LL (1988) SERVQUAL Instrument PsycTESTS Dataset.

13. Tanisah T, Maftukhah I (2015) The effects of service quality, customer satisfaction, trust, and perceived value towards customer loyalty. Jurnal Dinamika Manajemen 6.

14. Zhao J, Zhang M, Kong Q (2010) The Effect of Service Fairness on Service Quality, Customer Satisfaction and Customer Loyalty. 2010 International Conference on Management and Service Science.

15. Rothlin S, McCann D (2016) Customers: Marketing Ethics. Internationa Business Ethics 131-156.

16. Osobajo OA, Moore D (2017) The B2Com Relationship: An Empirical Study of the Measure of Relationship Quality in a Business-to-Community Relationship. International Business Research 10: 118.

17. Hsieh A, Li C (2008) The moderating effect of brand image on public relations perception and customer loyalty. Marketing Intelligence \& Planning 26: 26-42.

18. Alshurideh M, Al Kurdi BH, Vij A, Obiedat Z, Naser A (2016) Marketing Ethics and Relationship Marketing - An Empirical Study that Measure the Effect of Ethics Practices Application on Maintaining Relationships with Customers. International Business Research 9: 78.

19. Arasli H, Turan Katircioglu S, Mehtap-Smadi S (2005) A comparison of service quality in the banking industry. International Journal of Bank Marketing 23: 508-526.

20. Baumann C, Elliott G, Hamin H (2011) Modelling customer loyalty in financial services. International Journal of Bank Marketing 29: 247-267. 